Dieter Eissel

Justus Liebig University of Giessen, Germany

\title{
SHIFT FROM WELFARE STATE TO COMPETITION STATE CASE OF GERMANY
}

\section{GERMANY'S TRADITIONAL WELFARE SYSTEM}

The German social security system by tradition is confined largely to the working population. Additionally to the five pillars of social security (concerning pensions, health, accident, unemployment and care) the German welfare state is addressed to the family, the education system and the needy. There is no general cover for all inhabitants and the system generally does not extend to the selfemployed, although they can choose social insurance voluntarily. As a final safety net, there is a general social assistance programme that provides subsistence-level payments for those in need.

Whereas the traditional social security system is managed at the central state level, social assistance is an obligation of the local authorities. Social assistance is not a charitable donation, but following German social legislation is required to help people in situations which they cannot manage without support from outside. In these cases the needy are eligible for social assistance payments. The public task is to guarantee a subsistence minimum.

The German welfare state has its roots in the $19^{\text {th }}$ century, when the working class attacked the capitalist society and its state and aimed at a socialist alternative. To guarantee social peace the state reacted by introducing first steps of a general social security system equally financed by employers and their workers. The goal was and still is to guarantee acceptable public transfers when having lost wage income. Not to forget, the Bismarckian system in the end of $19^{\text {th }}$ century replaced existing self-help organisations of workers' associations, but was somehow effective to integrate the labour movement by an appeasement policy against revolutionary attitudes by providing following regulations:

statutory social insurance in case of having no earned income, because of:

- old age and surviving dependents,

- sickness,

- accident. 
The traditional principles of the Bismarckian type concerned shared contributions of each $50 \%$ by employers and employees. Further principles were:

- equivalence: receipts orientated to income and contributions (amount and years)

- orientated to the male bread winner system

- organised as self-governing organisations (three-partite, organisations of employers and employees, state).

Further steps of statutory social insurances followed nearly 30 years later in the time of the Weimar Republic concerning the unemployment insurance and foundation of labour offices in 1927. The last step was done in 1993 aiming at long-term nursing care insurance; now having 5 pillars of statutory social insurances.

Additional aspects of welfare concern:

- child-rearing benefits and children's allowance

- housing allowance

- equal opportunities in the educational system (main criterion for acceptance)

- justice of the tax system

Another tradition being older than the Bismarckian type of social security can be traced back to the local care for the needy. The care for the poor people was supported and guided by the principle of subsidiarity, published in 1891 by the Pope in his first "Social Encyclical". The main idea was to support self-help by the nearest social environment (family, neighbourhood, town and then state). The poor should be eligible to claim for welfare receipts providing to live under human conditions at the existence minimum level.

\section{TRANSFORMATION OF THE SOCIAL SECURITY SYSTEM}

Because of the relatively generous system of social services, in the past Germany's tax rates on corporations, individuals, and goods and services were relatively high in comparison with other countries. In the meantime far-reaching reforms have taken place since the 1980s, reaching their height during the period of the Red-Green governments (1998-2005). Since that time all the tradition of German welfare system and its principles and structures are undergone with reservations. Some describe the current development as a shift from social market to liberal market economy or from welfare state to competition state. The relatively new principles now are:

- privatisation: additional individual pay in case of sickness for doctors and medicine 
- supported private savings as adds on reduced pensions

- more pressure on unemployed (workfare model)

- welfare mix of institutions: family, market, state and third sector

- discussions about citizens' insurance system (including all: not only employees and workers up till a certain amount of wages but also officials (public servants and employers).

The core reforms are the so-called Hartz reforms named after the head of a commission and the "Agenda 2010" by former chancellor Schroeder. The structural changes of the given welfare state during the last 20 years clearly indicate that Germany's social security system has been under pressure. Those, insisting in a smooth reform are publicly announced as blocking forces whilst those engaging in a more liberal manner are perceived as modernists.

\section{PENSION SYSTEM UNDER PRESSURE}

Of course, the expenditures for pensions and health were by far the largest posts within the scheme of social expenditures. The total amount of social expenditures in Germany reached the enormous sum of 760.6 bn. Euros in 2010 $(=30,4 \%$ of GDP) of which expenditures for pensions and health care sum up to three quarters. This amount led to the widespread belief that the German social security system was overloaded and could not keep upright these costs in future, the more because demographic factors would worsen the situation. The relations between the active workforce and the elderly people has worsened: In 1950 the relation of the 20-64 years group to elderly people above 65 years was 6.2 : 1 ; this support coefficient has fallen to 3.7: 1 in 2000 and shall go down to a relation of 1.8: 1 in 2050. Rising life expectancy together with relatively lower birth rates and the related demographic shift constitute major challenges for the German system of old age security.

Table 1. Ageing society (\%)

\begin{tabular}{|c|c|c|c|c|}
\hline Year & Below 20 years & 20-65years & $65-80$ years & 80 and more years \\
\hline 1955 & 29.8 & 59.4 & 9.4 & 1.3 \\
\hline 2009 & 18.8 & 60.6 & 15.6 & 5.1 \\
\hline
\end{tabular}

Source: Federal Statistical Office of Germany: Datenreport 2011, p.14.

In addition, relatively high unemployment and a rising amount of the low wage sector (up to one quarter of the workforce) are causing a substantial loss 
in contribution revenue for the social security systems. Thus the pension system came under pressure. Reforms already adopted have intended to provide the basic answers needed to ensure the financial sustainability of statutory pensions. The extra expenditure arising from longer periods of pension receipt has to be shouldered jointly, and in a well-balanced manner, by the young and the old, by pensioners as well as those paying contributions and taxes. In taking pension-policy decisions, this approach will be supplemented by the principles of demographic sustainability, intergenerational equity and opportunities for labour market participation. The sustainability factor takes into account labour market and demographic changes so as not to increase contributions beyond 22 per cent until (at least) 2030. In addition, public pension entitlements are to fall slightly, and individuals are expected to provide for later life through private insurance plans (so-called Riester pension named after the former federal Minister for Labour and Social Policies). Nevertheless, this negative scenario is overdrawn if we count on continuing growth rates of productivity, leading to an enhanced GDP which could be distributed in an ageing society with a decreasing number of citizens.

Political proposals to fight unemployment at the same time aim at achieving a stabilization of pensions through a variety of measures such as increases in the statutory retirement age, changes to the pension revaluation formula and incentives for private insurance plans. According to the Commission's proposals, the statutory retirement age is to be raised from its current level of 65 years to 67 years by means of small-scale increases of one month per year, starting in 2011. Within the same time-frame, the age threshold for early retirement pensions is to be raised from 62 to 64 .

The core of the reform proposals is that rising costs of social security in an aging society are to be spread more evenly across all generations (ideal of inter-generational fairness) so as not to hinder employment and economic growth through high labour costs.

Regarding private pension plans, the Commission proposes:

1. Extension of eligibility for public pension bonuses to all taxpayers.

2. Dynamic increases of contribution thresholds up to which one is eligible for public bonuses to private pension schemes.

3. More transparency of private pension schemes.

4. Simplification of the bonus system.

5. Elimination of flat-rate taxation of certain private pension schemes.

In addition to the pension reform, the Commission's proposals cover health care and long-term care reforms. Pensions for the severely disabled are to be integrated into the major pension insurance scheme over the long run. 


\section{LABOUR MARKET REFORMS}

The labour market reforms have all pursued an activation strategy, i.e., they have attempted to increase employment and improve the nation's labour supply. Currently, the duration of unemployment benefits depends on the recipient's age and the length of former employment. The minimum of six months is granted after the employee has been employed and contributed to the public unemployment insurance fund for at least 12 months. The maximum duration of 32 months is achieved at age 57 with 64 months of previous employment. After the reform, only two levels of benefit duration will remain. In general, benefits will be uniformly provided for 12 months, regardless of previous employment duration. Only for those aged 55 years or more will benefits be granted for 18 months. Especially for older workers, this represents a sharp reduction in benefit duration. The reform must be viewed in light of the widespread use of unemployment insurance as a form of early retirement, especially in conjunction with pension eligibility due to unemployment. The reduction of unemployment benefits, especially for older workers, can be regarded as a first step towards the elimination of early retirement schemes. This is perceived as necessary to maintain the sustainability of social security in view of demographic changes, as long as additional financial burdens on either the active or the retired generation are regarded as undesirable.

However, this measure places the burden solely on the unemployed. It should be accompanied by improved and prolonged continuing training and by a less steep earnings profile over the individual's life-time in order to maintain the employability of older workers.

In addition, hire and fire was eased, and the unemployed had to face a paradigm change from welfare to workfare, urging unemployed to take over every job at any offered conditions or accepting cuts in their unemployment benefits. One of the sad effects was an upsurge of precarious work conditions like an emergent number of workers in the low wage sector and an increasing number of working poor. Within the ten years from 1998 to 2008 those working in the low wage sector increased from $13.5 \%$ of the total workforce to $19.1 \%$ (boeckler-impuls.de 22.9.2010). This is one of the reasons why trade unions strongly oppose the new labour market reforms and the curtailment of unemployment benefit periods. They argue that an unemployed person will be, on average, forced to take up a job earlier than under the status quo, leading to a potential mismatch between the employee's skills and the job's requirements. 
Some experts see the elements of the Agenda 2010 as steps in the right direction. Others remain sceptical regarding the scarcity of working places as the main problem of the labour market which can't be met by activation of the unemployed.

\section{CURRENT DILEMMA: INCREASING UNEMPLOYMENT, POVERTY, AND INEQUALITY}

In Germany, main challenges to the welfare system are concerning the relatively high rate of unemployment, and the increasing poverty. Unemployment is not only a waste of talents and thus a negative contribution to economic growth but leads to the highest risk of poverty. In addition high unemployment rates go along with lower acceptance of the given political and democratic structures and thus may endanger social peace.

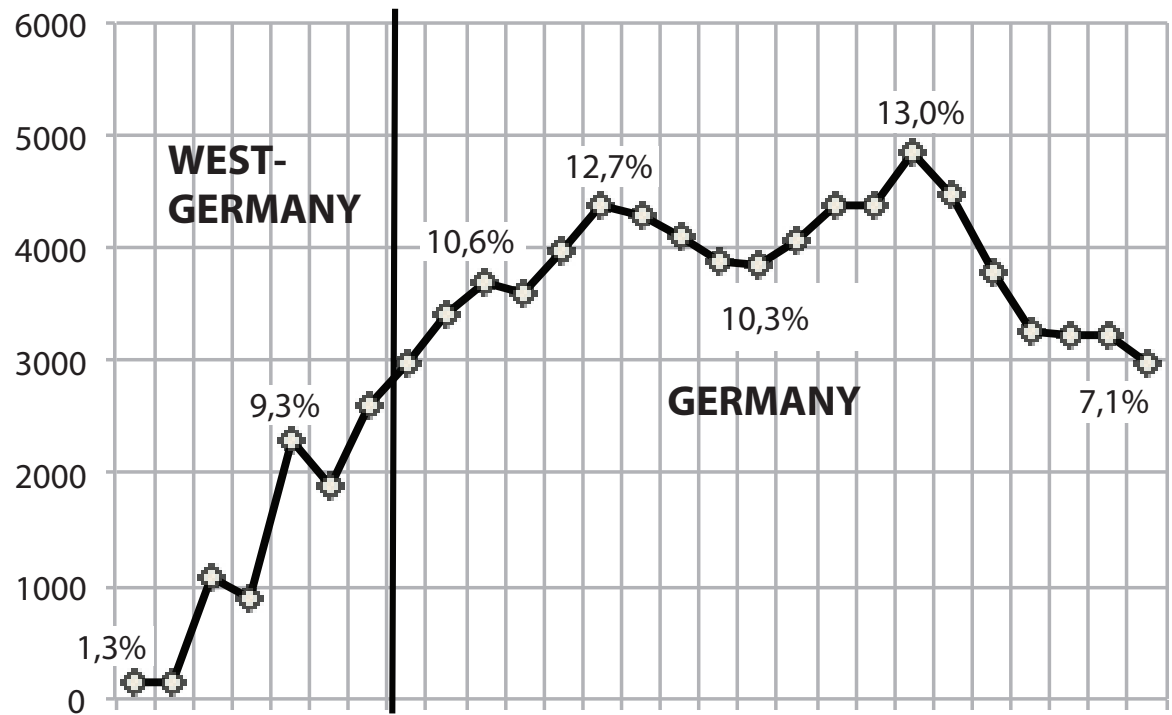

19651975198519911993199519971999200120032005200720092011

Figure 1. Unemployment in Germany in thousands and in \%

Source: Federal Statistical Office: Statistical Year Book 2009; Amtliche Nach-richten der Bundesagentur für Arbeit, 59. Jahrgang, Sondernummer 2, p. 53.

Not only jobless people but single parents - in most cases they are mothers - are affected by extraordinary poverty. The main problem for the single 
parents is that they can't afford to combine house work, education and paid work because of missing institutional child care. Thus, the young mothers - often being well educated - are forced to stay at home and cannot enter the labour market.

In the last decades the situation has worsened. Following the three reports on poverty and wealth in Germany published by the federal government since 2001 the number of those living under the poverty line increased. The data clearly show that among those, increasingly affected by poverty were unemployed and single parents, respectively their children. In the rich Germany more than 1 mill children lives under the poverty line.

Table 2. Increasing poverty* in Germany (Proportion of poor as a percentage of particular population groups)

\begin{tabular}{|l|c|c|}
\hline \multicolumn{1}{|c|}{ Population groups } & 1997 & $2007-2009$ \\
\hline All & 10.9 & 12.7 \\
\hline Men & 10.2 & 11.9 \\
\hline Women & 11.6 & 13.3 \\
\hline Children below 10 years & 12.9 & 12.3 \\
\hline Single parent, one child & 33.9 & 36.4 \\
\hline Married couples without children & 7.2 & 6.8 \\
\hline Unemployed & 30.6 & 53.3 \\
\hline
\end{tabular}

*Poverty line: $60 \%$ median.

Source: Federal Statistical Office: Datenreport 2006, 2011.

Not only did poverty rise but inequality, too. The GINI-coefficient data using the socio-economic panel clearly show rising inequality: From 1991 to 2007 the specific data for West-Germany show a rise from 0.396 to 0.461 and in EastGermany from 0.370 to 0.512 (SVR: 2009/10: 313, Table 39).

Table 3. Change of Income* and Wealth** Positions of Households

\begin{tabular}{|c|c|c|c|c|c|}
\hline & \multicolumn{2}{|c|}{$\begin{array}{c}\text { Adjusted equivalent market } \\
\text { income of households } \\
\text { (new OECD scale) }\end{array}$} & \multicolumn{2}{|c|}{ Net income of households } & Net wealth \\
\hline 1 & 2 & 3 & 4 & 5 & 6 \\
\hline & 1991 & 2009 & 1991 & 2009 & 2007 \\
\hline 1. decile & 0.2 & 0.1 & 4.1 & 3.6 & -1.6 \\
\hline 2. decile & 2.2 & 1.2 & 5.8 & 5.2 & 0 \\
\hline
\end{tabular}


Table 3. (cont.)

\begin{tabular}{|l|c|c|c|c|c|}
\hline \multicolumn{1}{|c|}{1} & 2 & 3 & 4 & 5 & 6 \\
\hline 3. decile & 4.7 & 2.8 & 6.8 & 6.3 & 0 \\
\hline 4. decile & 6.7 & 5.1 & 7.7 & 7.3 & 0.4 \\
\hline 5. decile & 8.3 & 7.2 & 8.5 & 8.2 & 1.2 \\
\hline 6. decile & 9.7 & 9.2 & 9.5 & 9.3 & 2.8 \\
\hline 7. decile & 11.5 & 11.3 & 10.6 & 10.3 & 6.0 \\
\hline 8. decile & 13.7 & 13.6 & 12.0 & 11.9 & 11.1 \\
\hline 9. decile & 17.0 & 17.7 & 17.3 & 14.2 & 19.0 \\
\hline 10. decile & 25.9 & 31.7 & 20.7 & 23.7 & 61.1 \\
\hline
\end{tabular}

Sources: *SVR, Jahresgutachten 2009/10 p. 316, tab. 40, SVR, Jahresgutachten 2011/12, p. 340 tab. 32 basis: socio-economic panel; ** Frick, Grabka 2009: 54-67.

The data specify that the lower half of all households in 2009 accounted for only $16.4 \%$ of market income, whilst the top $10 \%$ received $31.7 \%$. In comparison: in 1991 the lower $50 \%$ of households shared $22.1 \%$ and the top decile $25.9 \%$. Even after redistribution the disparity between the richest decile and the lower income groups has grown: The top decile gained 23.7\% of total net income in 2009 (1991: 20.7\%) whilst the lower half lost ground from $32.9 \%$ to $30.6 \%$.

Rising poverty on the one hand was accompanied with rising wealth on the other hand. Wealth development was even more unequal: In 2007 the top 10\% of income groups owned $61.1 \%$ of all assets, an increase of 3.2 percentage points since 2002. The lower half of the income groups had more or less no property. Taxes on properties, inheritance and donations are nevertheless very low. In 2007 their contribution to total state revenue was only $2.5 \%$, less than half the OECD average of $5.7 \%$.

By tradition of German social market system had put emphasis on minimizing this gap of market income by state redistribution. Like the founder of the social market concept had put it: "The income formation by the market economy 'leads' without doubt to income differences which socially is unwanted" (MüllerArmack 1947: 109). He therefore suggested direct income compensation between high and low incomes by an immediate income diversion. The ideal case of an intervention in conformity with the market is virtually given if the higher incomes are cut by taxation and these receipts are passed on approximately to poorer households in the form of direct child allowances, financial support for pensions" (Müller Armack 1947: 109). This clear demand for more equity and social justice in society has dramatically changed: Only the upper ten per cent of the households were winner of the distribution of income during the last two decades - even after 
redistribution, thus neglecting the social market goals. Since the 1980s this social market concept has lost its weight and was replaced by a market concept without the adjective social.

Not only private but additionally public poverty has grown, because the state forewent too much revenue, which enforced further cuts in the social security system, led to increasing privatisation of former publicly run enterprises (like water works, local energy supplies and traffic systems), and worsened the state's ability to invest in future infrastructure (above all in education).

\section{THE END OF FORDISM AND THE REBIRTH OF MARKET DOGMATISM}

The shift to neo-liberalism in Germany can be explained by the rising influence of employers' organisations, the right-wing mass media, a majority of economic advisers and political parties making use of the new uncertainties of global competition by urging governments to deregulate the existing labour market arrangements and to minimize the tax burden on profits. Additionally, trade unions were put under pressure to reduce wage costs. The growing dominance of this new economic philosophy was fuelled by a profound economic crisis of so-called Fordism (including mass production by assembly-line technology, high growth rates, rising wages, acceptance of trade unions, development of the welfare state and state interventionism in the spirit of Keynes). This crisis is rooted in the lower GDP growth rates in the early seventies in most Western countries where record levels of supply in many market segments was confronted with a deceleration in the dynamic of post-war demand. This downward demand-side was worsened in the seventies by the dramatic upsurge in oil prices in 1973-74. The price increases emanating from OPEC countries led to rapid break-downs in consumption and intensified the so-called stagflation (stagnation with simultaneous inflation). West Germany's GDP in 1975 fell by 1 per cent (in real terms), the first time since the founding of the FRG that it had fallen so sharply; it was accompanied by a rise in unemployment to more than one million people. The West German trade balance also fell as global demand declined and as the terms of trade deteriorated because of the rise in petroleum prices.

The USA, as "engine of the world economy", experienced additional inflationary effects through the Vietnam War. This wave of price increases, together with other factors, brought about the end of the so-called "Bretton-Woods-System" of fixed exchange-rates. This in turn caused a change in economic policy, generating the first wave of a world-wide liberalisation of financial markets and confronting the nation states and export-oriented companies with the new situation that 
exchange-rates were determined by the operations of free capital markets. The reaction of transnational corporations to fiercer global competition after the end of the post-war boom and to the new uncertainties of floating exchange rates, with the assistance of the US government, brought about the end of Fordism.

Politicians of nearly all parties in Germany have taken these challenges as necessity to be answered by a new wave of reforms concerning the social security system as well as given labour market regulations. The heading direction of the reforms can be seen as neo-liberal orientated, replacing the welfare state by the workfare state and leaving step by step the traditional social security system tracing back to Bismarck in the $19^{\text {th }}$ century by increasing privatization of the existing social risks in a market society.

This coincided with the rebirth of market dogmatism or the economic ideology of supply-sidism favoured by its idols like Milton Friedman (1962) and his Chicago school. Market-radical thinkers like Friedman and von Hayek have always either ignored or denied any threat to social cohesion and the resulting consequences for undisturbed economic growth. According to their view, freedom can only be secured through the limitation of the state to merely guaranteeing the free market order and stable prices and the liberation of economic dynamics. As early as 1944 Friedrich August von Hayek warned in his work 'The Road to Serfdom' (von Hayek 1944) against redistribution of the social product in the name of equality. Indeed, Hayek and others strictly demand that, in order to promote progress and economic growth, the rich should be treated moderately while the poor should not be supported. For Friedman welfare systems are the worst type of state intervention, being a fraud at the expense of all those who still go to work and pay taxes. Progressive income taxation with the aim of redistributing income is, according to him, an imposition and diametrically opposed to personal freedom. From this perspective he advocates low proportional income tax (Friedman 1971: 207). From the perspective of market dogmatism, union wage demands in addition endanger any improvement in employment opportunities, even if these demands remain within the boundaries of neutral distribution provided by inflation and the development of productivity. Accordingly, Hayek rather sees inequality itself as incentive for the poor to achieve more, with the luxurious life-style of the rich as a goal to which they can strive. If the rich are visibly better-off than the poor, an 'evolutionary process' is set in motion, since the poor also wish to acquire riches. For this reason, tax burdens imposed on large fortunes are vehemently rejected as economically and socially senseless measures of redistribution. High rates of taxation are adjudged to paralyse the preparedness of individuals and businesses to invest, and hence hinder economic activity; furthermore they would produce a flight from taxation and into the black economy. 
The freeing of the principle of profit-maximisation as the individual impetus for wealth creation was thus supposed to take priority over any commitment by the state to satisfy the needs of the masses.

This message was received with considerable enthusiasm by governments. The Reagan administration as well as Thatcher in Britain and, in the end, German administrations, orientated their economic policy according to this supply-side advice, starting in the 1980s with the result that state redistribution, mainly the effect of tax policy, favoured capital and produced a stagnation of wage income positions. Cutting back the welfare state, privatising public enterprises, deregulation and minimising production costs through wage and tax reductions were henceforth considered adequate strategies for surmounting the economic crisis caused by low GDP-rates and high unemployment.

International institutions like the European Union (EU), the Organisation for Economic Cooperation and Development (OECD), the International Monetary Fund (IMF), the World Trade Organisation (WTO) were weighty promoters of this process. Their measures have raised globalisation of the economy to new levels, which no nation state can ignore. Increased competition among companies and locations took place, exposing regions and even cities increasingly to the international economy, subjugating governments through the apparently neutral interplay of market forces and limiting increasingly the possibility for countries to develop their national economies independently. On the whole, the new politicoeconomic strategies since the mid-seventies have spurred world economic integration and the international division of labour. Market opportunities have increased, but competition is also growing. Therefore this form of economic globalisation highlights a shift of decision-making power from the state to the market, and from the welfare state to the 'competition' state.

The transnational corporations became the key economic actors after the mideighties, as they could obtain substantial cost savings through world-wide outsourcing. This produced a new dimension of globalisation, because TNCs were increasingly able to escape any form of political control and eased tax evasion.

\section{STATE'S SELF-IMPOVERISHMENT: TAX RACE TO THE BOTTOM}

Because of the worsening economic conditions, the conservative-liberal federal coalition which came to power with Chancellor Helmut Kohl in 1982 and governed for 16 years, began to direct what was termed the 'turn-around' (Wende). The government proceeded to implement new policies to reduce its role in the economy, following neo-liberal concepts. The broad policy included several main objectives: to reduce the federal deficit by cutting both expenditures 
and taxes, to reduce government restrictions and regulations, and to improve the flexibility of the labour market (Leaman 2009).

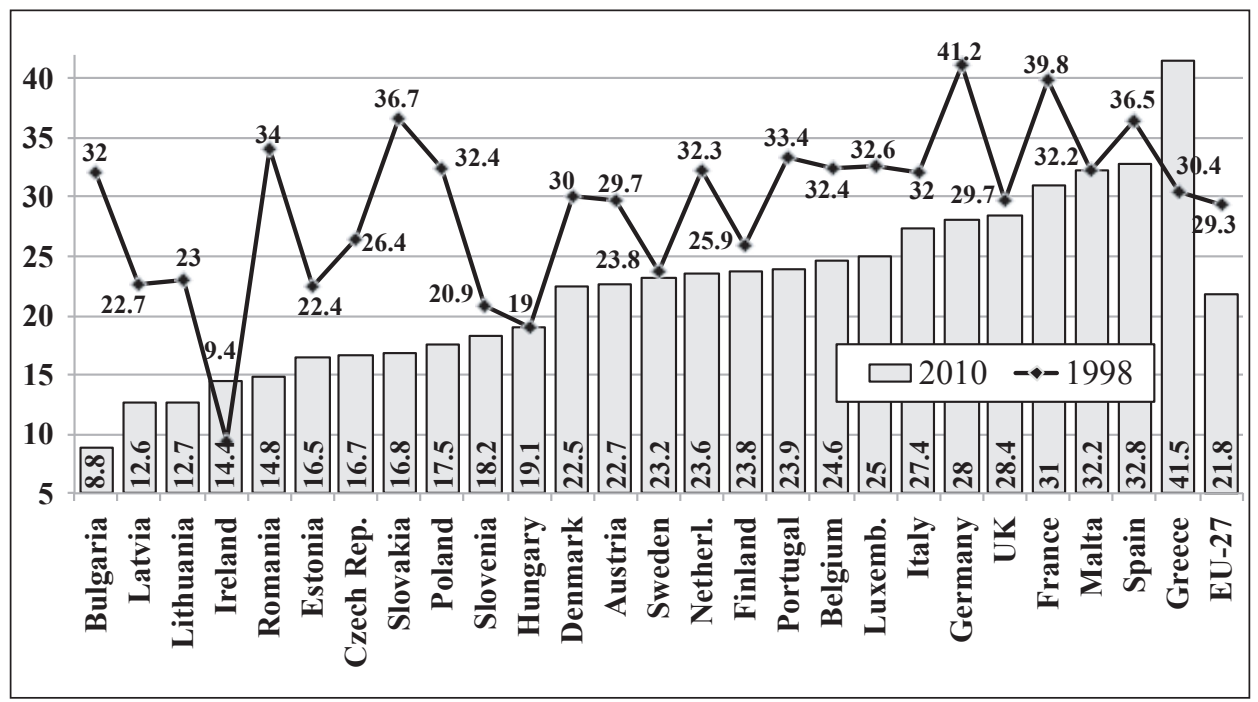

Figure 2. Implicit Tax Rates on Capital Income 1998 - 2010 (without finance sector) Source: Eurostat: Taxation Trends in the EU 2011: 133.

Step by step the tax load on capital income was reduced. The largest tax relief was done when the red-green government came to power in 1998. The top tax rate on income fell from $53 \%$ to $42 \%$. Above all the big companies as global players were released from taxes - throughout the European Union. Since 1995 till 2011 the average corporate tax rate on income fell from $35.2 \%$ to $23.1 \%$ (Eurostat: Taxation Trends in the EU 2011: 62). German big companies were among those benefitting to the largest degree. Their corporate tax rate on income dropped from $45 \%$ to under $20 \%$. The tax release should also benefit the wage earners but despite all tax reforms their contribution to total tax receipts remained high at about $30 \%$. In the end the state increased VAT by three per cent points to meet serious budget problems.

Obviously, the masses of wage earners and consumers had to pay the bill of tax reduction for the better-off and the big companies. The tax policy in the spirit of the neo-liberal credo did not reach its proclaimed goals. Just the opposite, it deepened the crisis and weakened state's capacity to meet the rising economic and social problems adequately. Nevertheless, only a minority of economic and social scientists criticized this policy, even if it was empirically evident that the supply side theory failed to deliver the adequate strategy to meet 
the challenges of competition and the importance of the private and public demand for economic growth. From an economic perspective, the poor results of the tax race to the bottom and stopping wage increase are not surprising: faced with the stagnation of domestic private and public demand, entrepreneurs behaved as could have been expected: there was no obvious reason to increase capacity through investments to meet static demand. Furthermore, despite rising rates of return overall, investments in real capital yielded increasingly lower returns than financial investments. The alternative then was to use additional accumulated profits for speculative purposes (qua casino capitalism), which was ultimately one of the factors behind the current finance crisis. So far, tax policy and redistribution favouring top incomes and incorporated businesses has clearly compounded the crisis. The impact of the finance crisis on the bank system then led to further problems because their bail-out increased the public debt, and this explosive increase of public deficit in return caused further cuts in expenditures following the EU mainstream austerity policy.

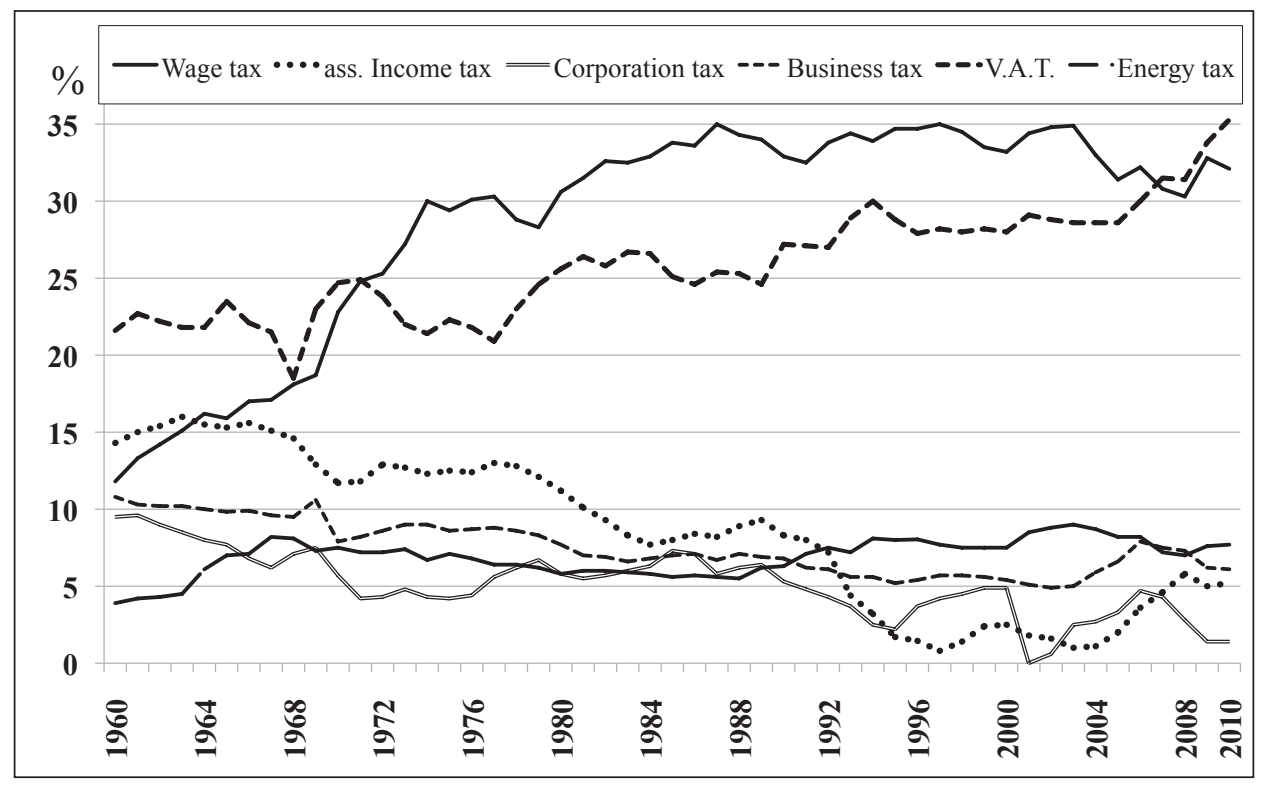

Figure 3. Tax development as \% of total tax receipts

Source: own calculation stat. Bundesamt; Wage tax before reduction of child allowance;

* AK Steuerschätzung vom Mai 2010.

With regard to factors for competition the crude supply side theory merely puts emphasis on costs factors like wage level and taxes neglecting several crucial 
points which are taken into consideration in case of investment planning. Above all the demand side is fully ignored aside some other important factors like political stability, availability of well trained workforce and infrastructure. The famous World Economic Forum named 12 pillars of competitiveness playing a role for investments related to different economic structures:

\begin{tabular}{|c|c|}
\hline $\begin{array}{ll}\text { Basic } & \text { Requirements } \\
\bullet & \text { Institutions } \\
\cdot & \text { Infrastructure } \\
\cdot & \text { Macroeconomic stability } \\
\text { - } & \text { Health and primary education }\end{array}$ & $\begin{array}{l}\text { Key for } \\
\text { Factor-driven } \\
\text { economies }\end{array}$ \\
\hline $\begin{array}{ll}\text { Efficiency Enhancers } \\
\text { - } & \text { Higher education and training } \\
\text { - } & \text { Goods market efficiency } \\
\text { - } & \text { Labour market efficiency } \\
\text { - } & \text { Financial market sophistication } \\
\text { - } & \text { Technological readiness } \\
\text { - } & \text { Market size }\end{array}$ & $\begin{array}{l}\text { Key for } \\
\text { Efficiency-driven } \\
\text { economies }\end{array}$ \\
\hline $\begin{array}{l}\text { Innovation and sophistication factors } \\
\text { - } \quad \text { Business sophistication } \\
\text { - } \quad \text { Innovation }\end{array}$ & $\begin{array}{l}\text { Key for } \\
\text { Innovation-driven } \\
\text { Economies }\end{array}$ \\
\hline
\end{tabular}

Figure 4. Pillars of Competitiveness

Source: World Economic Forum, The Global Competitiveness Report 2008/09.

However, the daily brain-washing oriented towards supply-sidism was somehow successful. It persuaded the majority of the electorate that maintaining existing levels of tax on capital and relatively high wage levels, capital would shun Germany and go to cheaper locations with continuing harmful effects for employment security.

\section{EFFECTS OF RE-UNIFICATION AND FINANCE CRISIS}

Aside the negative impacts of market dogmatism on the welfare state and on public finance we have to count on further - in part special - effects that had restrictive impacts on the public budget: here we have to see the costs 
of the re-unification and since 2008 the costs (mainly bailout for banks) of the current crisis.

Table 4. State Finance and Social Budget as \% of GDP

\begin{tabular}{|l|c|c|c|c|c|c|}
\hline & 1970 & 1980 & 1990 & 1992 & 2000 & 2010 \\
\hline Tax Receipts & 25.5 & 23.8 & 21.6 & 22.3 & 24.4 & 22.2 \\
\hline Social Contributions & 16.7 & 22.4 & 22.5 & 18.0 & 19.4 & 19.4 \\
\hline Debt absolute bn. euro & 61.9 & 232.9 & 527.7 & 680.8 & 1198.1 & 1951.1 \\
\hline Debt as \% of GDP & 18.2 & 31.4 & 43.2 & 42.9 & 59.7 & 83.2 \\
\hline Social Budget & 22.5 & 27.3 & 25.0 & 26.4 & 28.3 & 29.2 \\
\hline
\end{tabular}

Source: Federal Ministry of Labour and Social Affairs (BMAS), Statistisches Taschenbuch 2011.

The level of social security spending increased dramatically at all levels, because of the integration of East German Laender into the Western legal structures following reunification. Facing the enormous costs of reunification the German governments of the Kohl and as well the Schroeder era did not react by rising taxation but on the opposite tried to cover the expenditures via increasing debt escorted by reducing the tax load, latter declared as necessary step to improve Germany's economic competition in a continuing globalisation.

The debt crisis got worse after the real estate crisis and its succeeding bank and budget crisis hit the public budget. Nevertheless, the crucial cause for the budget crisis has to be seen in the tax policy following the neo-liberal credo.

Examining the results, the effects remained nevertheless poor. There is empirical evidence that the top-down re-distribution, favouring capital returns, was a flop. The so-called "reforms" (which is a reinterpretation of the former positive meaning of the word) during the Schroeder era had no clear positive effect on improving the sluggish economy. The German case shows that the government's tax gifts helped to increase the net returns of capital, but failed to encourage investments in jobs, favouring capital market investments instead. Following the neoliberal credo, the government rather reduced the tax burden on the rich and thus increased both private and public poverty. Because of lower state revenues, further state expenditure to safeguard the social net would have led to rising indebtedness, which on the other hand would contravene the Maastricht criteria.

The competition state as meagre state caused a social and economic calamity. Instead of strengthening economic growth it endangered investments for needed growth conditions for the future, which first hand are dependent on public investments in infrastructure and human capital. 


\section{REFERENCES}

Bundesagentur für Arbeit (2013), Amtliche Nachrichten 59.Jg. Sondernr. 2

Eurostat (2011). Taxation trends in the European Union.

Federal Statistical Office (2011), Statistical Yearbook 2011, Wiesbaden.

Frick J.R., Grabka M.M. (2004), Gestiegene Vermögensungleichheit in Deutschland, "DIWWochenbericht", vol. 4.

Friedman M. (1971), Capitalism and Freedom, Chicago: Chicago University Press.

Leaman J. (2009), The Political Economy of Germany under Chancellors Kohl and Schröder, New York-Oxford: Berghahn.

Müller-Armack A. (1947), Wirtschaftslenkung und Marktwirtschaft, Hamburg: Verlag für Wirtschaft und Sozialpolitik.

von Hayek F.A. (1944), The Road to Serfdom, Chicago: University of Chicago Press.

Dieter Eissel

\section{OD PAŃSTWA OPIEKUŃCZEGO DO PAŃSTWA OPARTEGO NA KONKURENCJI. PRZYPADEK NIEMIEC}

(streszczenie)

Niegdyś najbardziej emblematyczny przykład konserwatywnego reżimu welfare, typu Bismarckowskiego, niemiecka społeczna ekonomia rynkowa podlegała zasadniczym zmianom w okresie ostatnich piętnastu lat. Nowa agenda dotyczyła głównie: prywatyzacji niektórych usług wcześniej zapewnianych przez państwo, częściowa komercjalizacja systemu emerytalnego, wprowadzenie rozwiązań typu welfare mix w wielu sferach systemu znaczyło przemianę z modelu welfare do modelu workfare, szczególnie w odniesieniu do rynku pracy. Autor śledzi tę transformację, wskazując na najważniejsze czynniki, które przyczyniły się do zmian w odniesieniu do systemu emerytalnego, ubezpieczeń zdrowotnych, rynku pracy i polityki podatkowej. Ponadto analizuje polityczny kontekst oraz społeczne konsekwencje wdrożenia neoliberalnego programu. 